\title{
Genotoxic effects of mercury chloride on the Neotropical fish Andinoacara rivulatus (Cichlidae: Cichlasomatini)
}

\author{
Mauro Nirchio ${ }^{1,2}$, Oscar Choco-Veintimilla ${ }^{1}$, Patricio Fredy Quizhpe-Cordero' ${ }^{1}$, \\ José Gregorio Hernández ${ }^{2} \&$ Claudio Oliveira ${ }^{3}$ \\ 1. Universidad Técnica de Machala, Facultad de Ciencias Agropecuarias, Av. Panamericana Km. 5 1/2 Vía a Pasaje, \\ Machala, Ecuador; manirchio@utmachala.edu.ec, oscar_choco_15@hotmail.com, pquizhpe@utmachala.edu.ec, \\ joshernandez2006@gmail.com \\ 2. Universidad de Oriente, Núcleo Nueva Esparta, Porlamar, Venezuela; mauro.nirchio@gmail.com \\ 3. Departamento de Morfologia, Instituto de Biociências, Universidade Estadual Paulista, Sao Paulo, Brazil; \\ claudio@ibb.unesp.br
}

Received 29-VII-2018. Corrected 10-V-2019. Accepted 26-VI-2019.

\begin{abstract}
Understanding the effects of heavy metals in aquatic ecosystems is of significant importance due to their potential to bioaccumulate at various trophic levels and induce damage in DNA. Mercury is considered one of the most dangerous heavy metals, causing chromosomal breakage (clastogenic event) or spindle dysfunction (aneugenic event), that can lead to the formation of encapsulated chromatin into a separate smaller nucleus, generally referred to as a micronucleus. We evaluated the sensitivity of the micronucleus test in the neotropical cichlid Andinoacara rivulatus (Günther 1860). The fish were divided into four groups of 16 individuals, and each group was placed in separate aquaria $(140 \mathrm{~L})$ provided with filtered water and constant aeration. Fish were exposed to mercury chloride $\left(\mathrm{HgCl}_{2}\right)$ at doses $0.1,0.25$, and $0.50 \mathrm{mg} / \mathrm{kg}$ body weight, administered by intraperitoneal (IP) injection. Fish from the control group were injected with a physiologic solution. The following erythrocyte anomalies were identified: erythrocytes with micronuclei varying to some extent in size and position in the cytoplasm, blebbed nucleus, binucleated cell, nuclei showing a deep invagination toward the center (notched nuclei). Examination of blood smears demonstrated a higher level of micronucleus and notched erythrocytes in fish injected with $\mathrm{HgCl}_{2}$ than in the controls. There were significant differences in the frequency of micronucleated and notched erythrocytes among the groups exposed to mercury. Linear regression analysis revealed a positive relationship between the frequency of micronucleated and notched erythrocytes $(\mathrm{P}<0.0001)$, with a moderately strong correlation coefficient $(\mathrm{R}=0.737)$. We propose that, in addition to the two so far known mechanisms of micronucleus formation (spindle apparatus damage and chromosomal ruptures), chromatin fragmentation in notched nuclei resulting from a combination of the cytotoxic effects of mercury and mechanical stress, may be a third mechanism of micronuclei genesis.
\end{abstract}

Key words: micronuclei; erythrocyte nuclear abnormalities; DNA damage; heavy metal; fish.

Nirchio, M., Choco-Veintimilla, O., Quizhpe-Cordero, P. F., Hernández, J. G. \& Oliveira, C. (2019). Genotoxic effects of mercury chloride on the Neotropical fish Andinoacara rivulatus (Cichlidae: Cichlasomatini). Revista de Biología Tropical, 67(4), 745-754.

Heavy metals released into aquatic ecosystems from industrial, agricultural, and domestic sources, municipal sewage treatment plants, and from other anthropogenic activities have the potential to bioaccumulate at various trophic levels and can induce damage in DNA (Mitchelmore \& Chipman, 1998; Ohe, Watanabe, \& Wakabayashi; 2004, Bolognesi, Perrone, Roggieri, Pampanin, \& Sciutto, 2006; Isani et al., 2009; Sharifuzzaman et al. 2016). 
Thus, given the extreme toxicity of heavy metals, understanding their effects in aquatic ecosystems is of significant importance.

Mercury is one of the most dangerous heavy metals, causing deleterious effects on biota (W.H.O., 1990; Buhl, 1997; Rocha et al. 2011a; Anual, 2014; Nabi, 2014; Kandroo, Tripathi, \& Sharma, 2015; Morcillo, Esteban, \& Cuesta, 2017). This toxicant interferes with the formation of the mitotic spindle during cell division, causing the contraction of chromosomes, a delay in the division of the centromere, and a slower movement during anaphase, as well as chromosomal breakage (Skerfving, Hansson, \& Lindsten, 1970; Catherine Ferens \& United States, 1974; Thier, Bonacker, Stoiber, \& Böhm, 2003). Chromatin fragments derived from chromosomal breakage (clastogenic event) or spindle dysfunction (aneugenic event), or even whole chromosomes in the case of chromosome lag, do not migrate to the poles during anaphase and are included in the daughter cells, becoming encapsulated into a separate smaller nucleus, generally referred to as a micronucleus (Miller,1973; Miller et al., 1998; Wirzinger, Weltje, Gercken, \& Sordyl, 2007).

Fishes have a greater ability to metabolize xenobiotics, accumulate pollutants, and are capable of inhabiting practically all zones of the aquatic habitat. In addition, unlike mammals, fish erythrocytes are nucleated and have been shown to be more sensitive to the induction of DNA damages (Mir et al., 2014). These characteristics make them an excellent model for assessing the potential danger of chemicals introduced into the aquatic environment. Indeed it has been shown that after exposure to different pollutants under field and laboratory conditions the peripheral erythrocytes of fishes have a higher incidence of micronuclei formation (Al-Sabti \& Hardig, 1990; Heddle et al., 1991; Vanparys, Deknudt, Vermeiren, Sysmans, \& Marsboom, 1992; Torres de Lemos, Rödel, Terra, D'Avila de Oliveira, \& Erdtmann, 2007; Ali, El-Shehawi, \& Seehy, 2008; Yadav \& Trivedi, 2009; Monteiro, Cavalcante, Viléla, Sofia, \& Martinez, 2011; Özkan, Gündüz, Berköz, \& Hunt, 2011; Bakar, Ashriya, Shuib,
\& Razak, 2014; Fatima et al. 2014; Vignardi et al, 2015; Ivanova \& Popovska-Percinic, 2016). Therefore, fishes are suitable organisms in which to evaluate the clastogenic and aneugenic effects of genotoxic compounds, with the assay being called the micronucleus test (MNT), a widely applied method due to its simplicity, reliability, sensitivity, and adaptive suitability (Carrasco, Tilbury, \& Myers, 1990; Al-Sabti \& Metcalfe, 1995; Udroiu, 2006; Junín, Rodríguez, Heras, \& Braga, 2008). Indeed, research on clastogenic or mutagenic effects in neotropical fish has become increasingly common (Cestari et al., 2004; Rocha et al., 2011b; Zapata et al., 2016).

Some authors have observed, in addition to micronucleated erythrocytes (MNE), the occurrence of other nuclear abnormalities (ENAs), such as blebbed, lobed, binucleated, and notched nuclei, suggesting that these anomalies should be considered analogous to MNs, and, therefore, should be taken into consideration as potential indicators of cytotoxicity (Carrasco et al., 1990; Ayllon \& Garcia-Vazquez, 2000, 2001; Çavaş \& Ergene-Gözükara, 2003, 2005; da Silva Souza \& Fontanetti, 2006; Matsumoto et al., 2006; Ergene et al., 2007; Jiraungkoorskul et al., 2007; Costa et al., 2008; Monteiro et al., 2011; Tasneem \& Yasmeen, 2018). Our preliminary, unpublished observations, showed a significant proportion of erythrocytes with notched nuclei in fish exposed to mercury, leading us to investigate if this nuclear anomaly could be effectively employed as a genotoxic marker. Thus, in the present study, we assessed the proportion of MNE and notched erythrocytes (NE) after the administration of mercury chloride in Andinoacara rivulatus (Günther 1860), a freshwater teleost fish naturally distributed from the north of Ecuador to the north of Peru, and also spread throughout the world as an aquarium pet colloquially known as Vieja Azul or Green Terror.

\section{MATERIALS AND METHODS}

All specimens used in this study were acquired from a stock obtained via induced 
reproduction that is carried out by the repopulation program of the species in La Tembladera Wetland, in El Oro Province of Ecuador (http:// asogrotem.org/). Fish were transported in plastic bags to the laboratory and acclimated for $24 \mathrm{~h}$.

Bioassay, blood sampling and smear preparation: Fish were divided into four groups of 16 individuals, and each group was placed in separate aquaria (140 L) provided with filtered water and constant aeration. Fish were not fed while the test was ongoing. Mercury chloride $\left(\mathrm{HgCl}_{2}\right)$ was administered by a single intraperitoneal (IP) injection (Al-Sabti $\&$ Metcalfe, 1995). Concentrations of 20, 50, and $100 \mu \mathrm{g} / \mathrm{ml}$ of mercury were used in a ratio of $0.5 \mathrm{ml}$ of solution per $100 \mathrm{~g}$ of weight $(0.1$, 0.25 , and $0.50 \mathrm{mg} \mathrm{HgCl}_{2} / \mathrm{Kg}$ ). Fish from the control group were injected with a physiologic solution. The mercury doses tested were chosen considering the mercury content $(\mathrm{mg} / \mathrm{kg})$ reported in some freshwater species of teleosts (Cyprinus carpio Linnaeus 1758, 0.1-0.5, max. 0.8; Gambusia affinis (Baird \& Girard 1853), max. 0.5; Lepomis macrochirus Rafinesque 1819, 0.1-0.3, max. 0.41; Micropterus salmoides (Lacepède 1802) 0.35-0.85, max. 1.9) (Saiki, Jennings, \& May, 1992). Four individuals from each group were randomly selected every $24 \mathrm{~h}$ until $96 \mathrm{~h}$, and peripheral blood smears were prepared by draining blood via caudal vein puncture using a syringe without anticoagulant. All the fish were anesthetized with benzocaine before blood extraction. The fish of the control group were immediately released while the fish injected with mercury were euthanized with anesthetic overdose, incinerated and the ashes placed in plastic bags and buried in a landfill. Smears were airdried, fixed in absolute ethanol for $20 \mathrm{~min}$, and stained with $10 \%$ Giemsa in phosphate buffer (pH 6.88) for $20 \mathrm{~min}$. Three slides per fish were mounted using Canada balsam and archived until evaluation. The procedures were conducted in accordance with Institutional Authorization Research Project 396/2016, Universidad Técnica de Machala and Protocol number 1027 for experiments with animals of Universidade Estadual Paulista "Julio de Mesquita Filho".

Cell scoring: On each plate, a series of 15-20 photographs were taken at random with an Olympus BX53 photomicroscope (1 $000 \mathrm{x}$ magnification) to guarantee that no fewer than 1000 cells/slide were counted. Scoring was performed on the digital images by a single observer. The frequencies of MNE and/or NE were expressed per 1000 counted cells.

Statistical analysis: Levene's and Kolmogorov-Smirnov tests were applied to check the homoscedasticity and normality, respectively. Since data obtained did not present a normal distribution and violated the homogenous variance principle for both MNE and NE frequencies, they were square root transformed to normalize and homogenize the variances. Then, data were analyzed by two-way ANOVA and Fisher's Least Significant Difference (LSD) post-hoc test $(\mathrm{P} \leq 0.05)$ for comparison of differences among groups. The relationship between MNE and NE frequencies was analyzed using linear regression analysis by the least squares method. Pearson's correlation coefficients were calculated between NE and MNE. The entire analysis was done with the statistical package STATGRAPHICS ${ }^{\circledR}$ Centurion XVI (version 16.1.18).

\section{RESULTS}

Fish exposed to $0.50 \mathrm{mg} / \mathrm{kg}$ of $\mathrm{HgCl}_{2}$ died progressively during the period of the experiment. At $96 \mathrm{~h}$ only one fish was still alive in this group. Therefore, data from this group were excluded for statistical analysis. The analysis of peripheral blood smears of the studied fish showed that normal erythrocytes appeared with an oval shape and a centric ellipsoid nucleus with well-defined boundary (Fig. 1A). The following nuclear abnormalities were found: small, non-refractive circular/ ovoid particles in the cytoplasm resembling a nucleus with respect to staining properties were considered an MNE varying to some extent in 

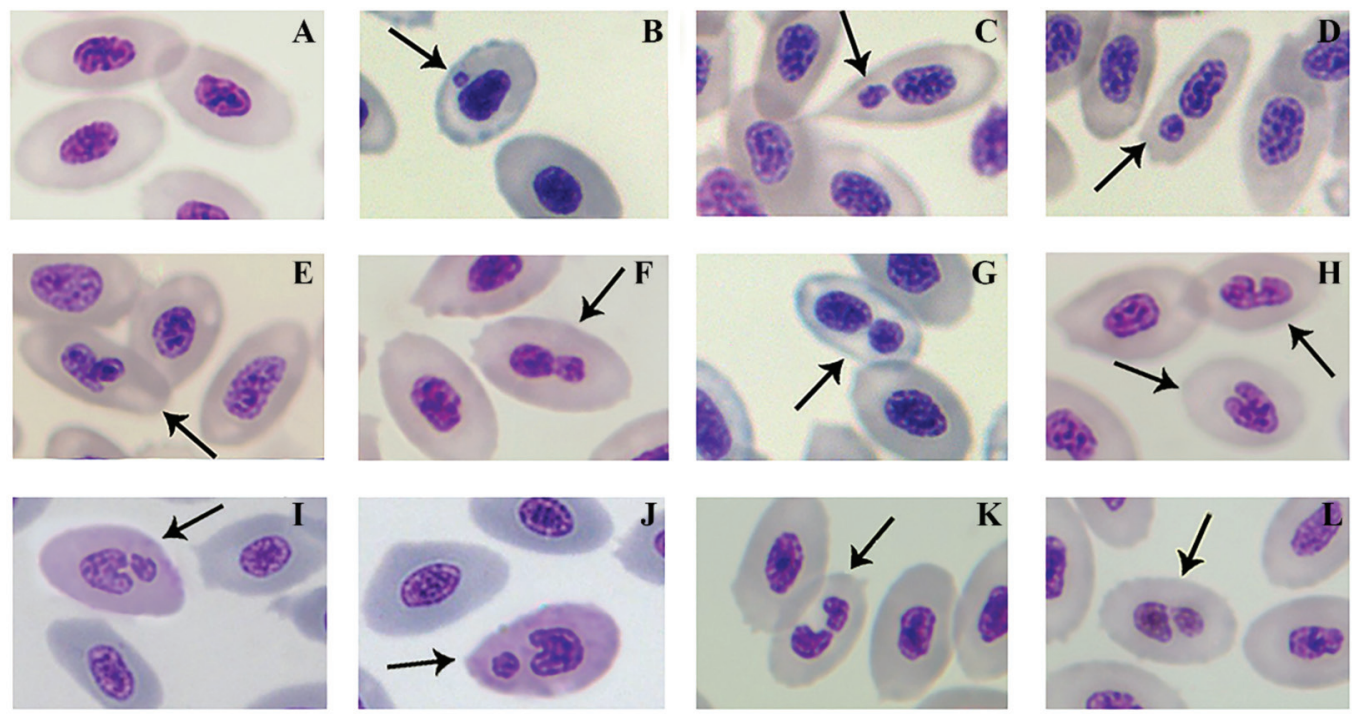

Fig. 1. Photomicrographs showing cells with normal nucleus (A) and nuclear abnormalities (arrows) in peripheral blood erythrocytes of Andinoacara rivulatus exposed to $\mathrm{HgCl}_{2}$ : micronuclei (B, C, D), blebbed nucleus $(\mathbf{E}, \mathbf{F})$, binucleated cell (G), Notched nucleus (H), putative fragmented notched nucleus (L).

size and position in the cytoplasm (Fig. 1B, Fig, 1C, Fig. 1D); blebbed nucleus appeared as a small evagination of the nuclear envelope resembling a micronucleus (Fig. 1E, Fig. 1F); binucleated cell contains two nuclei that are not attached and relatively similar in size (Fig. 1G); nuclei showing a deep invagination toward the center were considered an NE (Fig. $1 \mathrm{H}$ ). Some fractured notched nuclei were also observed (Fig. 1I, Fig. 1J, Fig. 1K, Fig. 1L).

Compared with the control group, fish exposed to $\mathrm{HgCl}_{2}$ showed an increase in the frequency of MNE and NE with a peak in MNE $24 \mathrm{~h}$ after dosing (Fig. 2). Two-way ANOVA with three levels of concentration of $\mathrm{HgCl}_{2}(0$, $0.1,0.25 \mathrm{mg} / \mathrm{kg}$ ) and four levels of exposure time $(24,48,72,96 \mathrm{~h})$, followed by a post-hoc LSD test revealed significant differences in the MNE and NE among groups exposed to different concentrations of $\mathrm{HgCl}_{2}$ (Table 1). Simple linear regression analysis between the frequency of MNE and NE (Fig. 3) revealed a moderately strong relationship $(\mathrm{F}=54.84, \mathrm{P}<$ $0.0001)$, with the linear model

$$
\sqrt{M N E \%}=-0,28801+0,2957 \sqrt{N E \%}
$$

and a correlation coefficient $\mathrm{R}=0.74$. The adjusted model explains $54.38 \%$ (R2) of the variability in $\sqrt{M N E \%}$.

\section{DISCUSSION}

Fish exposed to $\mathrm{HgCl}_{2}$ showed an increase in the frequency of MNE and NE, demonstrating that the species here studied is sensitive to mercury at the concentration used. Similar time-dependent effects in MNE frequency were also reported in Oreochromis niloticus (Linnaeus 1758), Phoxinus phoxinus (Linnaeus 1758), and Poecilia latipinna (Lesueur 1821) exposed to different heavy metals (Ayllon \& GarciaVazquez, 2000; Jiraungkoorskul et al., 2007).

Differences in sensitivity to the induction of MNE and other erythrocyte nucleus anomalies among fish species have been reported after IP injection of mercurial compounds in Salmo trutta Linnaeus 1758, P. phoxinus (Sanchez-Galan et al., 1999), and Channa punctata (Bloch 1793) (Yadav \& Trivedi 2009). Here, a low frequency of MNE and NE in the control group indicates that a percentage of these 

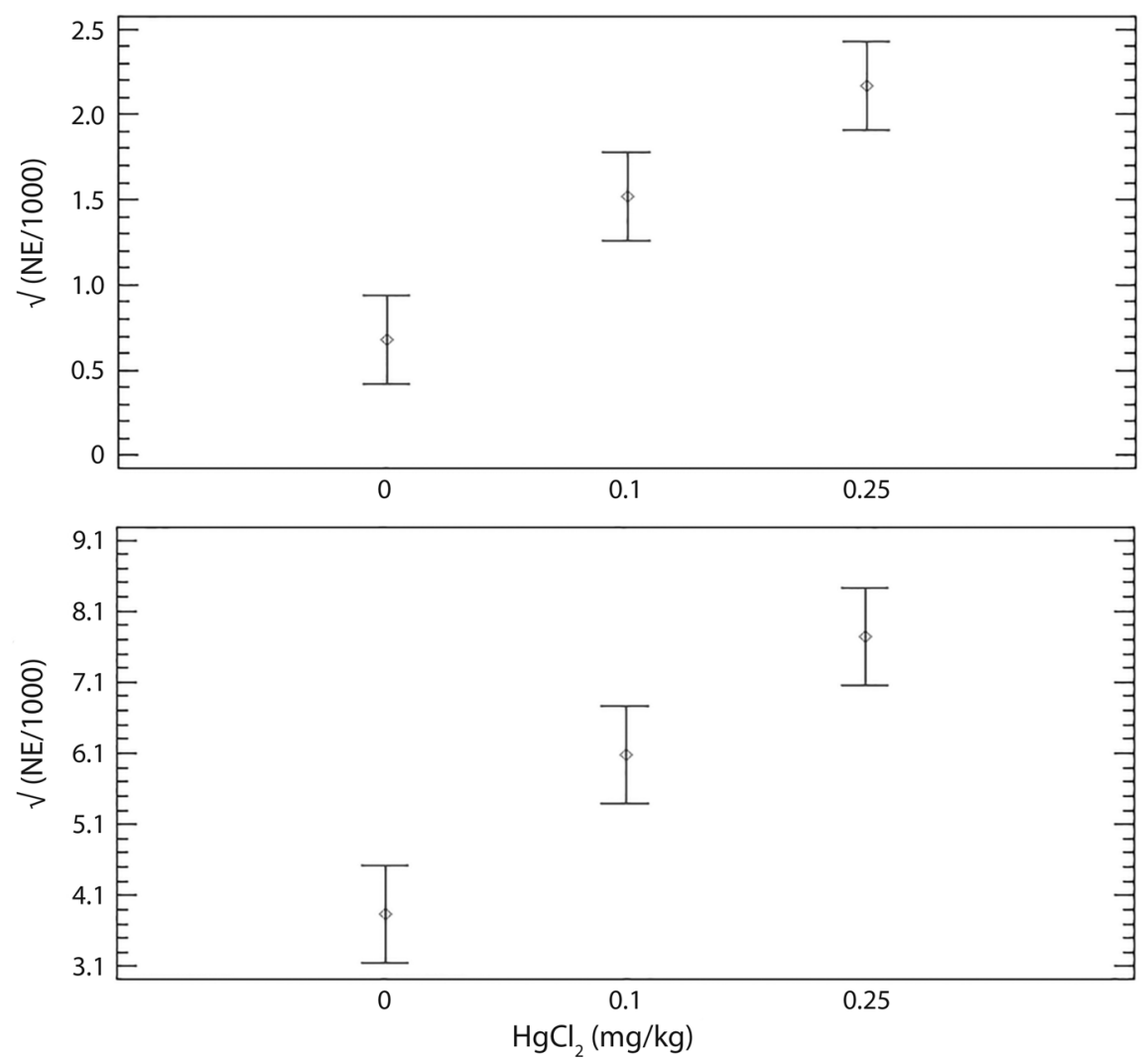

Fig. 2. Frequency of micronucleated erythrocytes (MNE) and erythrocytes with notched nucleus (NE) in Andinoacara rivulatus exposed to $\mathrm{HgCl}_{2}(\mathrm{mg} / \mathrm{kg}$ ). Bars represent $95 \%$ Fisher's Least Significant Difference.

TABLE 1

Mean \pm standard deviation of micronuclei $(\mathrm{MN})$, notched nuclei (Notch), and MN+Notch per 1000 erythrocytes in Andinoacara rivulatus injected with two doses of $\mathrm{HgCl}_{2}$ and subjected to $96 \mathrm{~h}$ of exposure

\begin{tabular}{|c|c|c|c|c|c|c|c|}
\hline $\mathrm{HgCl}_{2}(\mathrm{mg} / \mathrm{g})$ & $\mathrm{n}$ & $\sqrt{\mathrm{MN}}$ & LSD & $\sqrt{\text { Notch }}$ & LSD & $\sqrt{ }(\mathrm{MN}+$ Notch $)$ & LSD \\
\hline 0 & 16 & $0.68 \pm 0.56$ & $\mathrm{X}$ & $3.84 \pm 1.75$ & $\mathrm{X}$ & $3.93 \pm 1.75$ & $\mathrm{X}$ \\
\hline 0.1 & 16 & $1.52 \pm 0.94$ & $\mathrm{X}$ & $6.08 \pm 2.40$ & $\mathrm{X}$ & $6.31 \pm 2.46$ & $\mathrm{X}$ \\
\hline 0.25 & 16 & $2.15 \pm 0.92$ & $\mathrm{X}$ & $7.71 \pm 1.76$ & $\mathrm{X}$ & $8.05 \pm 1.79$ & $\mathrm{X}$ \\
\hline ANOVA & \multicolumn{3}{|c|}{$\mathrm{F}=16.96^{* * *} \mathrm{p}=0.0002$} & $\mathrm{~F}=16.90^{* * *} \mathrm{p}=0.000$ & \multicolumn{3}{|c|}{$\mathrm{F}=19.20^{* * *} \mathrm{p}=0.000$} \\
\hline Time $(\mathrm{H})$ & $\mathrm{n}$ & $\sqrt{\mathrm{MN}}$ & LSD & $\sqrt{ }$ Notch & LSD & $\sqrt{ }(\mathrm{MN}+$ Notch $)$ & LSD \\
\hline 24 & 12 & $1.86 \pm 1.09$ & $\mathrm{X}$ & $5.29 \pm 2.12$ & $\mathrm{X}$ & $7.03 \pm 2.29$ & $X$ \\
\hline 48 & 12 & $1.35 \pm 0.97$ & $\mathrm{XX}$ & $5.33 \pm 2.52$ & $\mathrm{X}$ & $5.57 \pm 2.54$ & $\mathrm{X}$ \\
\hline 72 & 12 & $0.94 \pm 0.83$ & $\mathrm{X}$ & $6.19 \pm 2.54$ & $\mathrm{X}$ & $5.41 \pm 2.58$ & $\mathrm{X}$ \\
\hline 96 & 12 & $1.66 \pm 1.03$ & $\mathrm{X}$ & $6.75 \pm 2.93$ & $\mathrm{X}$ & $6.43 \pm 3.05$ & $\mathrm{X}$ \\
\hline ANOVA & \multicolumn{3}{|c|}{$\mathrm{F}=3.77 * \mathrm{p}=0.0189$} & $\mathrm{~F}=0.195^{\mathrm{ns}} \mathrm{p}=0.1950$ & \multicolumn{3}{|c|}{$\mathrm{F}=1.92^{\mathrm{ns}} \mathrm{p}=0.1433$} \\
\hline Interaction $\mathrm{HgCl}_{2}$ & ime & $\mathrm{F}=1.88^{\mathrm{ns}} \mathrm{p}=0.11$ & & $\mathrm{~F}=1.35^{\mathrm{ns}} \mathrm{p}=0.25$ & & $\mathrm{~F}=1.57^{\mathrm{ns}} \mathrm{p}=0$. & \\
\hline
\end{tabular}

F-tests (F) and probability values (p) on Analysis of Variance (ANOVA) with results of post-hoc test (LSD) for establishing significantly different means are shown. 


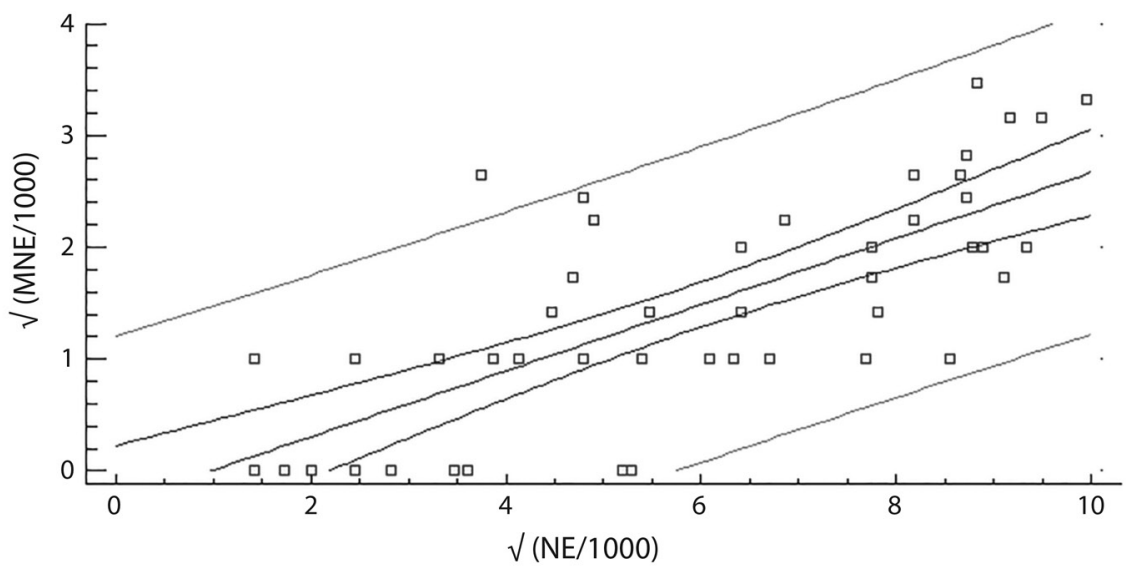

Fig. 3. Regression between micronucleated erythrocytes (MNE/1 000) and cells with notched nuclei (NE/1 000). Data was square root transformed.

abnormalities were generated naturally. Indeed, spontaneous micronucleus frequencies (control) have been observed in several species of fish such as Astyanax bimaculatus (Linnaeus 1758) (Matsumoto \& Cólus, 2000), S. trutta, Anguilla anguilla (Linnaeus 1758), P. phoxinus (Rodriguez-Cea, Ayllon, \& Garcia-Vazquez, 2003), Mullus barbatus Linnaeus 1758 (Bolognesi et al., 2006), Rhamdia quelen (Quoy \& Gaimard 1824), C. carpio, Hypostomus punctatus Valenciennes 1840, O. niloticus (Salvagni, Ternus, \& Fuentefria, 2011), and Colossoma macropomum (Cuvier 1816) (Rocha et al., 2011b), with analogous frequency to that found in this study.

Cell populations treated with a genotoxic agent must undergo mitosis for MNE to appear (Savage, 2000; Harding et al., 2017). In fishes, erythrocytes arise from small lymphoid hemoblasts maintained by continuous mitotic divisions in the intertubular tissues of the kidney, although in some fishes like trout, the spleen is also active, while in others like perch, only the spleen is active (Catton, 1951). In fishes, a peak in micronucleated erythrocytes occurs 1-5 days after exposure to genotoxic substances, but in most species, it takes place after 2 or 3 days (Udroiu, 2006). Thus, the MNE peak here detected at $24 \mathrm{~h}$ suggests that mitotic spindle poisoning and/or the clastogenic effects of mercury (or their reactive metabolites) arose from already active mitotic cells after dosing. By the contrary, the lower frequency of $\mathrm{MN}$ after 72 and $96 \mathrm{~h}$ of exposure could be a result of a weakening of the normal process of cell division (mitosis) in the hematopoietic tissues, probably produced by the toxic effect of mercury. Indeed, the decrease in the erythrocyte count in Astronotus ocellatus (Agassiz, 1831), Anabas scandens (Daldorff, 1797), Salmo trutta caspius Kessler, 1877; Hypophthalmichthys molitrix (Valenciennes, 1844), exposed to chronic doses of mercurial compounds has been attributed to the impairment of erythropoiesis due to direct effect of this heavy metal (Rodríguez et al., 2017).

The results of linear regression analysis revealed that an increase in the frequency of notched cells was accompanied by a proportional increase in micronuclei bearing cells, with a high significant correlation index $(\mathrm{R}=0.74 ; \mathrm{P}<0.0001)$, suggesting a direct relationship between these nuclear anomalies. These data are congruent with previous results obtained in other fishes like Clarias gariepinus (Burchell, 1822), Alburnus orontis Sauvage, 1882, Mugil cephalus Linnaeus, 1758 (Ergene et al., 2007), Dicentrarchus labrax (Linnaeus, 1758), and Mugil spp. Linnaeus, 1758 (Strunjak-Perovic, Topic Popovic, CozRakovac, \& Jadan, 2009a). The cytotoxicity of mercury compounds causes damage in cell 
function, resulting in the inability of cells to proliferate (Silva-Pereira et al., 2005). Studies in rats exposed to $\mathrm{HgCl}_{2}$ have shown that this metal has a high affinity for chromatin in the cell nucleus (Rózalski \& Wierzbicki, 1979) and studies on the effect of mercury on the nucleus of Dictyostelium discoideum Raper, 1935, a species of soil-living amoeba recognized as a model organism by the American National Institute of Health (http://www.nih. gov/science/model), revealed that $10 \mathrm{mM}$ of $\mathrm{HgCl}_{2}$ provokes an increase in MNE frequency, in addition to the carbonylation and quantitative changes in nuclear proteins (Boatti et al., 2017). Other compounds, such as the herbicide sulfentrazone, have induced MNE and nuclear DNA fragmentation on Allium cepa L. cells (Bianchi et al., 2016).

Mechanisms of erythrocyte nuclei deformity have not yet been explained and there is no consensus about the causes of these changes (Strunjak-Perovic, Coz-Rakovac, Topic Popovic, \& Jadan, 2009a, 2009b). Recently, it has been proposed that severe nuclear deformations can also originate from physical forces, such as the compression of the nucleus during migration through confined spaces that can lead to nuclear envelope rupture (Shah, Wolf, \& Lammerding, 2017).

Although further studies are required to explain the mechanisms involved in the concomitant variation of $\mathrm{MNE}$ and $\mathrm{NE}$ in $A$. rivulatus, it is likely that mechanical stress might contribute to generation of chromatin fragmentation. In other words, in addition to the known cytotoxic effects of mercury on spindle apparatus damage and chromosomal ruptures, local defects in nuclear envelope might also results from a third mechanism linked to mechanical stress.

\section{ACKNOWLEDGMENT}

This work was supported by Centro de Investigaciones of Universidad Técnica de Machala, Ecuador, and Consejo de Investigación, Universidad de Oriente, Venezuela.

\section{RESUMEN}

Efectos genotóxicos del cloruro de mercurio en el pez neotropical Andinoacara rivulatus (Cichlidae: Cichlasomatini). Comprender los efectos de los metales pesados en los ecosistemas acuáticos es de gran importancia debido a su potencial de bioacumulación en los diversos niveles tróficos y de inducir daños en el ADN. El mercurio, considerado uno de los metales pesados más peligrosos, causa fracturas cromosómicas (evento clastogénico) o disfunción del huso mitótico (evento aneugénico), y puede conducir a la formación de fragmentos de cromatina encapsulada en un núcleo separado más pequeño, generalmente denominado micronúcleo. En este trabajo se evalúa la sensibilidad del test de micronúcleos en el cíclido neotropical Andinoacara rivulatus (Günther 1860). Los peces fueron divididos en cuatro grupos de 16 individuos, y cada grupo se colocó en acuarios separados $(140$ L) provistos de agua filtrada y aireación constante. Los peces fueron expuestos al cloruro de mercurio $\left(\mathrm{HgCl}_{2}\right)$ en dosis de $0.1,0.25$ y $0.50 \mathrm{mg} / \mathrm{kg}$ de peso corporal, administrada por inyección intraperitoneal (IP). Los peces del grupo control fueron inyectados con solución fisiológica. Se identificaron las siguientes anomalías en los eritrocitos: micronúcleos que varían en tamaño y posición en el citoplasma, núcleo con evaginaciones, células binucleadas núcleos con muesca (núcleos con una profunda invaginación hacia el centro). El examen de los frotis de sangre demostró un mayor nivel de eritrocitos micronucleados y con muesca en peces inyectados con $\mathrm{HgCl}_{2}$ que en los controles. Fueron detectadas diferencias significativas en la frecuencia de eritrocitos micronucleados y células con núcleos con muescas entre los grupos expuestos al mercurio. El análisis de regresión lineal reveló una relación positiva entre la frecuencia de eritrocitos micronucleados y con muescas $(\mathrm{P}<0.0001)$, con un coeficiente de correlación moderadamente fuerte $(\mathrm{R}=$ 0.737). Se propone que, además de los dos mecanismos hasta ahora conocidos de formación de micronúcleos (daño del huso mitótico y rupturas cromosómicas), la fragmentación de la cromatina en núcleos con muesca probablemente a causa de la combinación de los efectos citotóxicos del mercurio y el estrés mecánico, podría ser un tercer mecanismo de génesis de micronúcleos.

Palabras clave: micronúcleos; anomalías nucleares de eritrocitos; daño en el ADN; metal pesado; peces.

\section{REFERENCES}

Ali, F., El-Shehawi, A. M., \& Seehy, M. A. (2008). Micronucleus test in fish genome: A sensitive monitor for aquatic pollution. African Journal of Biotechnology, 7(5), 606-612.

Al-Sabti, K., \& Hardig, J. (1990). Micronucleus test in fish for monitoring the genotoxic effects of industrial waste products in the Baltic Sea, Sweden. Comparative Biochemistry and Physiology. Part C, 
Pharmacology, Toxicology \& Endocrinology, 97(1), 179-182.

Al-Sabti, K., \& Metcalfe, C. D. (1995). Fish micronuclei for assessing genotoxicity in water. Mutation Research/Genetic Toxicology, 343(2), 121-135.

Anual, Z. F. (2014). Exposure assessment for mercury and other metals in commonly consumed fish of west peninsular Malaysia (Doctoral dissertation). University of Canberra, Australia. Retrieved from http://www.canberra.edu.au/researchrepository/ file/403f57d5-f954-4210-89cf-433251e64cb1/1/ full_text.pdf

Ayllon, F., \& Garcia-Vazquez, E. (2000). Induction of micronuclei and other nuclear abnormalities in European minnow Phoxinus phoxinus and mollie Poecilia latipinna: an assessment of the fish micronucleus test. Mutation Research/Genetic Toxicology and Environmental Mutagenesis, 467(2), 177-186.

Ayllon, F., \& Garcia-Vazquez, E. (2001). Micronuclei and other nuclear lesions as genotoxicity indicators in rainbow trout Oncorhynchus mykiss. Ecotoxicology and Environmental Safety, 49(3), 221-225.

Bakar, S., Ashriya, A., Shuib, A. S., \& Razak, S. A. (2014). Genotoxic effect of zinc and cadmium following single and binary mixture exposures in tilapia (Oreochromis niloticus) using micronucleus test. Sains Malaysiana, 43(7), 1053-1059.

Bianchi, J., Fernandes, T. C. C., \& Marin-Morales, M. A. (2016). Induction of mitotic and chromosomal abnormalities on Allium cepa cells by pesticides imidacloprid and sulfentrazone and the mixture of them. Chemosphere, 144, 475-483.

Boatti, L., Rapallo, F., Viarengo, A., \& Marsano, F. (2017) Toxic effects of mercury on the cell nucleus of Dictyostelium discoideum. Environmental Toxicology, $32(2), 417-425$.

Bolognesi, C., Perrone, E., Roggieri, P., Pampanin, D. M., \& Sciutto, A. (2006). Assessment of micronuclei induction in peripheral erythrocytes of fish exposed to xenobiotics under controlled conditions. Aquatic Toxicology, 78, 93-98.

Buhl, K. J. (1997). Relative sensitivity of three endangered fishes, Colorado squawfish, bonytail, and razorback sucker, to selected metal pollutants. Ecotoxicology and Environmental Safety, 37(2), 186-192.

Carrasco, K. R., Tilbury, K. L., \& Myers, M. S. (1990). Assessment of the Piscine Micronucleus Test as an in situ Biological indicator of Chemical Contaminant Effects. Canadian Journal of Fisheries and Aquatic Sciences. Journal Canadien Des Sciences Halieutiques et Aquatiques, 47(11), 2123-2136.

Catherine Ferens, M., \& United States. Environmental Protection Agency. Office of Research and Development.
(1974). A review of the physiological impact of mercurials. USA: U.S. Govt. Print. Off.

Catton, W. T. (1951). Blood cell formation in certain teleost fishes. Blood, 6(1), 39-60.

Çavaş, T., \& Ergene-Gözükara, S. (2003). Micronuclei, nuclear lesions and interphase silver-stained nucleolar organizer regions (AgNORs) as cyto-genotoxicity indicators in Oreochromis niloticus exposed to textile mill effluent. Mutation Research/Genetic Toxicology and Environmental Mutagenesis, 538(1), 81-91.

Çavaş, T., \& Ergene-Gözükara, S. (2005). Induction of micronuclei and nuclear abnormalities in Oreochromis niloticus following exposure to petroleum refinery and chromium processing plant effluents. Aquatic Toxicology, 74(3), 264-271.

Cestari, M. M., Lemos, P. M. M., Ribeiro, C. A. de O., Costa, J. R. M. A., Pelletier, E., Ferraro, M. V. M., Mantovani, M. S., \& Fenocchio, A. S. (2004). Genetic damage induced by trophic doses of lead in the neotropical fish Hoplias malabaricus (Characiformes, Erythrinidae) as revealed by the comet assay and chromosomal aberrations. Genetics and Molecular Biology, 27(2), 270-274.

Costa, P. M., Lobo, J., Caeiro, S., Martins, M., Ferreira, A. M., Caetano, M., Vale, C., Delvalls, T. A., \& Costa, M. H. (2008). Genotoxic damage in Solea senegalensis exposed to sediments from the Sado Estuary (Portugal): effects of metallic and organic contaminants. Mutation Research, 654(1), 29-37.

Ergene, S., Çavaş, T., Çelik, A., Köleli, N., Kaya, F., \& Karahan, A. (2007). Monitoring of nuclear abnormalities in peripheral erythrocytes of three fish species from the Goksu Delta (Turkey): genotoxic damage in relation to water pollution. Ecotoxicology, 16(4), 385-391.

Fatima, M., Usmani, N., Mobarak Hossain, M., Siddiqui, M. F., Zafeer, M. F., Firdaus, F., \& Ahmad, S. (2014). Assessment of genotoxic induction and deterioration of fish quality in commercial species due to heavymetal exposure in an urban reservoir. Archives of Environmental Contamination and Toxicology, 67(2), 203-213.

Harding, S. M., Benci, J. L., Irianto, J., Discher, D. E., Minn, A. J., \& Greenberg, R. A. (2017). Mitotic progression following DNA damage enables pattern recognition within micronuclei. Nature, 548(7668), 466-470.

Heddle, J. A., Cimino, M. C., Hayashi, M., Romagna, F., Shelby, M. D., Tucker, J. D., Vanparys, P., \& MacGregor, J. T. (1991). Micronuclei as an index of cytogenetic damage: past, present, and future. Environmental and Molecular Mutagenesis, 18(4), 277-291. 
Isani, G., Andreani, G., Cocchioni, F., Fedeli, D., Carpené, E., \& Falcioni, G. (2009). Cadmium accumulation and biochemical responses in Sparus aurata following sub-lethal Cd exposure. Ecotoxicology and Environmental Safety, 72(1), 224-230.

Ivanova, L., \& Popovska-Percinic, F. (2016). Micronuclei and nuclear abnormalities in erythrocytes from Barbel Barbus peloponnesius revealing genotoxic pollution of the river Bregalnica. Macedonian Journal of Chemistry and Chemical Engineering, 39(2), 159-166.

Jiraungkoorskul, W., Kosai, P., Sahaphong, S., Kirtputra, P., Chawlab, J., \& Charucharoen, S. (2007). Evaluation of micronucleus test's sensitivity in freshwater fish species. Research Journal of Environmental Sciences, 1(2), 56-63.

Junín, M., Rodríguez Mendoza, N., Heras, M., \& Braga, L. (2008). Valoración preliminar de la utilización de bioindicadores de contaminación en algunas especies de peces del delta del río Paraná, argentina. Ciencias Ambientales, 1, 17-24.

Kandroo, M., Tripathi, N. K., \& Sharma, I. (2015). Detection of micronuclei in gill cells and haemocytes of fresh water snails exposed to mercuric chloride. International Journal of Recent Scientific Research, 6(8), 5725-5730.

Matsumoto, F. E., \& Cólus, I. M. S. (2000). Micronucleus frequencies in Astyanax bimaculatus (Characidae) treated with cyclophosphamide or vinblastine sulfate. Genetics and Molecular Biology, 23(2), 489-492.

Matsumoto, S. T., Mantovani, M. S., Malaguttii, M. I. A., Dias, A. L., Fonseca, I. C., \& Marin-Morales, M. A. (2006). Genotoxicity and mutagenicity of water contaminated with tannery effluents, as evaluated by the micronucleus test and comet assay using the fish Oreochromis niloticus and chromosome aberrations in onion root-tips. Genetics and Molecular Biology, 29(1), 148-158.

Miller, B., Pötter-Locher, F., Seelbach, A., Stopper, H., Utesch, D., \& Madle, S. (1998). Evaluation of the in vitro micronucleus test as an alternative to the in vitro chromosomal aberration assay: position of the GUM working group on the in vitro micronucleus test. Mutation Research/Reviews in Mutation Research, 410(1), 81-116.

Miller, R. C. (1973). The micronucleus test as an in vivo cytogenetic method. Environmental Realth Perspectives, 6, 167-170.

Mir, M. I., Khan, S., Bhat, S. A., Reshi, A. A., Shah, F. A., Balki, M. H., \& Manzoor, R. (2014). Scenario of genotoxicity in fishes and its impact on fish industry. IOSR-JESTFT, 8(6), 2319-2402.

Mitchelmore, C. L., \& Chipman, J. K. (1998). DNA strand breakage in aquatic organisms and the potential value of the comet assay in environmental monitoring. Mutation Research, 399(2), 135-147.

Monteiro, V., Cavalcante, D. G. S. M., Viléla, M. B. F. A., Sofia, S. H., \& Martinez, C. B. R. (2011). In vivo and in vitro exposures for the evaluation of the genotoxic effects of lead on the Neotropical freshwater fish Prochilodus lineatus. Aquatic Toxicology, 104(3-4), 291-298.

Morcillo, P., Esteban, M. A., \& Cuesta, A. (2017). Mercury and its toxic effects on fish. Environmental Science, 4, 386-402.

Nabi, S. (2014). Toxic Effects of Mercury. notoxicity of freshwater ecosystem shows DNA damage in preponderant fish as validated by in vivo micronucleus induction in gill and kidney erythrocytes. Mutation Research. Genetic Toxicology and Environmental Mutagenesis, 775, 20-30.

Ohe, T., Watanabe, T., \& Wakabayashi, K. (2004). Mutagens in surface waters: a review. Mutation Research, $567,109-149$.

Özkan, F., Gündüz, S. G., Berköz, M., \& Hunt, A. Ö. (2011). Induction of micronuclei and other nuclear abnormalities in peripheral erythrocytes of Nile tilapia, Oreochromis niloticus, following exposure to sublethal cadmium doses. Turkish Journal of Zoology, 35(4), 585-592.

Rocha, C., Cavalcanti, B., Pessoa, C. Ó., Cunha, L., Pinheiro, R. H., Bahia, M., \& Burbano, R. M. R. (2011a). Comet assay and micronucleus test in circulating erythrocytes of Aequidens tetramerus exposed to methylmercury. In Vivo, 25(6), 929-933.

Rocha, C. A. M. da, Cunha, L. A. da, Pinheiro, R. H. da S., Bahia, M. de O., \& Burbano, R. M. R. (2011b). Studies of micronuclei and other nuclear abnormalities in red blood cells of Colossoma macropomum exposed to methylmercury. Genetics and Molecular Biology, 34(4), 694-697.

Rodriguez-Cea, A., Ayllon, F., \& Garcia-Vazquez, E. (2003). Micronucleus test in freshwater fish species: an evaluation of its sensitivity for application in field surveys. Ecotoxicology and Environmental Safety, $56(3), 442-448$.

Rodríguez, A.P.C., Maciel, P. \& Silva, L. C. P. 2017. Chronic Effects of Methylmercury on Astronotus ocellatus, an Amazonian Fish Species. Journal of Aquatic Pollution and Toxicology, 1, 1-14.

Rózalski, M., \& Wierzbicki, R. (1979). Binding of mercury by chromatin of rats exposed to mercuric chloride. Environmental Research, 20(2), 465-469.

Saiki, M. K., Jennings, M. R., \& May, T. W. (1992). Selenium and other elements in freshwater fishes from the irrigated San Joaquin valley, California. The Science of the Total Environment, 126(1), 109-137. 
Salvagni, J., Ternus, R. Z., \& Fuentefria, A. M. (2011). Assessment of the genotoxic impact of pesticides on farming communities in the countryside of Santa Catarina State, Brazil. Genetics and Molecular Biology, 34(1), 122-126.

Sanchez-Galan, S., Linde, A. R., \& Garcia-Vazquez, E. (1999). Brown trout and European minnow as target species for genotoxicity tests: differential sensitivity to heavy metals. Ecotoxicology and Environmental Safety, 43(3), 301-304.

Savage, J. R. (2000). Micronuclei: pitfalls and problems. Atlas of Genetics and Cytogenetics in Oncology and Haematology, 4(4):229-233.

Shah, P., Wolf, K., \& Lammerding, J. (2017). Bursting the Bubble--Nuclear Envelope Rupture as a Path to Genomic Instability? Trends in Cell Biology, 27(8), 546-555.

Sharifuzzaman, S. M., Rahman, H., Ashekuzzaman, S. M., Islam, M. M., Chowdhury, S. R., \& Hossain, M S. (2016). Heavy Metals Accumulation in Coastal Sediments. In H. Hasegawa, I. M. M. Rahman, \& M. A. Rahman (Eds.), Environmental Remediation Technologies for Metal-Contaminated Soils (pp. 21-42). Tokyo: Springer Japan.

Silva-Pereira, L. C., Cardoso, P. C. S., Leite, D. S., Bahia, M. O., Bastos, W. R., Smith, M. A. C., \& Burbano, R. R. (2005). Cytotoxicity and genotoxicity of low doses of mercury chloride and methylmercury chloride on human lymphocytes in vitro. Brazilian Journal of Medical and Biological Research, 38(6), 901-907.

da Silva Souza, T., \& Fontanetti, C. S. (2006). Micronucleus test and observation of nuclear alterations in erythrocytes of Nile tilapia exposed to waters affected by refinery effluent. Mutation Research/ Genetic Toxicology and Environmental Mutagenesis, 605(1-2), 87-93.

Skerfving, S., Hansson, K., \& Lindsten, J. (1970). Chromosome breakage in humans exposed to methyl mercury through fish consumption. Preliminary communication. Archives of Environmental Health, 21(2), 133-139.

Strunjak-Perovic, I., Coz-Rakovac, R., Topic Popovic, N., \& Jadan, M. (2009b). Seasonality of nuclear abnormalities in gilthead sea bream Sparus aurata (L.) erythrocytes. Fish Physiology and Biochemistry, 35(2), 287-291.

Strunjak-Perovic, I., Topic Popovic, N., Coz-Rakovac, R., \& Jadan, M. (2009a). Nuclear abnormalities of marine fish erythrocytes. Journal of Fish Biology, 74(10), 2239-2249.

Tasneem, S., \& Yasmeen, R. (2018). Induction of Micronuclei and Erythrocytic Nuclear Abnormalities in Peripheral Blood of Fish Cyprinus carpio on Exposure to Karanjin. Iranian Journal of Toxicology, 12(2), $37-43$.

Thier, R., Bonacker, D., Stoiber, T., Bohm, K. J., Wang, M., Unger, E., Bolt, H. M., \& Degen, G. (2003). Interaction of metal salts with cytoskeletal motor protein systems. Toxicology Letters, 140, 75-81.

Torres de Lemos, C., Milan Rödel, P., Regina Terra, N., Cristina D'Avila de Oliveira, N., \& Erdtmann, B. (2007). River water genotoxicity evaluation using micronucleus assay in fish erythrocytes. Ecotoxicology and Environmental Safety, 66(3), 391-401.

Udroiu, I. (2006). The micronucleus test in piscine erythrocytes. Aquatic Toxicology, 79(2), 201-204.

Vanparys, P., Deknudt, G., Vermeiren, F., Sysmans, M., \& Marsboom, R. (1992). Sampling times in micronucleus testing. Mutation Research, 282(3), 191-196.

Vignardi, C. P., Hasue, F. M., Sartório, P. V., Cardoso, C. M., Machado, A. S. D., Passos, M. J., Santos, T. C., Nucci, J. M., Hewer, T. L., Watanabe, I. S., Gomes, V., \& Phan, N. V. (2015). Genotoxicity, potential cytotoxicity and cell uptake of titanium dioxide nanoparticles in the marine fish Trachinotus carolinus (Linnaeus, 1766). Aquatic Toxicology, 158, 218-229.

Wirzinger, G., Weltje, L., Gercken, J., \& Sordyl, H. (2007). Genotoxic damage in field-collected three-spined sticklebacks (Gasterosteus aculeatus L.): a suitable biomonitoring tool? Mutation Research, 628(1), 19-30.

W.H.O. (1990). Methylmercury. Environmental health criteria 101. Geneva: World Health Organization.

Yadav, K. K., \& Trivedi, S. P. (2009). Sublethal exposure of heavy metals induces micronuclei in fish, Channa punctata. Chemosphere, 77(11), 1495-1500.

Zapata Restrepo, L. M., Orozco Jiménez, L. Y., Rueda Cardona, M., Echavarría, S. L., \& Palacio Baena, J. A. (2016). Evaluación genotóxica del agua del Río Grande (Antioquia, Colombia) mediante frecuencia de eritrocitos micronucleados de Brycon henni (Characiformes: Characidae). Revista de Biología Tropical, 65(1), 405-414. 